\title{
Platyhelminthes, Trematoda, Digenea Carus, 1863: Distribution extension in Argentina and new Anura and Ophidia hosts
}

\author{
Lía Inés Lunaschi* and Fabiana Beatriz Drago \\ Museo de La Plata, Laboratorio de Helmintología. Paseo del Bosque S/№, 1900. La Plata, Buenos Aires, Argentina. \\ * Corresponding author. E-mail: lunaschi@fcnym.unlp.edu.ar
}

\begin{abstract}
The aim of this paper is to increase the knowledge on the diversity of digenean parasites in ophidians and anurans from northeastern Argentina. Specimens of the snakes Eunectes notaeus, Hydrodynastes gigas, Micrurus corallinus, Philodryas sp. and Sibynomorphus sp., and the anurans Rhinella schneideri, Phyllomedusa azurea and Leptodactylus latrans were examined. Twelve digenean species were identified: Catadiscus corderoi Mañé-Garzón, 1958, Catadiscus dolichocotyle (Cohn, 1903), Catadiscus uruguayensis Freitas \& Lent, 1939, Choledocystus elegans (Travassos, 1926), Gorgoderina parvicava Travassos, 1922, Haplometroides buccicola Odhner, 1911, Heterodiplostomum lanceolatum Dubois, 1936, Infidum similis Travassos, 1916, Mesocoelium monas (Rudolphi, 1819), Plagiorchis luehei (Travassos, 1927), Telorchis clava (Diesing, 1850) and Travtrema stenocotyle (Cohn, 1902). New host species and/or new locality records from Argentina are presented.
\end{abstract}

The available information on the digeneans of Argentinean reptiles and anurans is scarce; 313 reptile species were reported in this country, but only 50 species (16\%) have been studied for digeneans; whereas only $12(7 \%)$ of the 171 Argentinean amphibian species were reported as host of adult digeneans (Lunaschi and Drago 2007). In this paper, we analyze samples from frogs, toads, and snakes captured in natural ecosystems impacted by deforestation and rural activities in the northeastern of Argentina.

The investigation was based on the study of the digeneans collected between March 1997 and March 2002 in different localities of Misiones, Chaco, Corrientes and Formosa Provinces, Argentina (Figure 1). The ophidians examined were: Hydrodynastes gigas (Duméril) (n = 1), Philodryas sp. $(\mathrm{n}=1)$, Sibynomorphus sp. $(\mathrm{n}=1)$, (Dipsadidae); Eunectes notaeus Cope ( $\mathrm{n}=1)$ (Boidae), and Micrurus corallinus (Merrem) ( $\mathrm{n}=1$ ) (Elapidae). The anurans studied were: Rhinella schneideri (Werner) $(\mathrm{n}=2)$ (Bufonidae), Phyllomedusa azurea Cope $(\mathrm{n}=17)$ (Hylidae), and Leptodactylus latrans (Steffen) $(\mathrm{n}=10)$ (Leptodactylidae). The digenean specimens were fixed in hot formalin, preserved in $70 \%$ ethanol, flattened and stained with a 1:6 $96^{\circ}$ ethanol dilution of hydrochloric carmine, dehydrated and mounted in Canada balsam. The specimens were deposited in the Helminthological Collections of Museo de La Plata (MLP), La Plata, Argentina. The taxonomy of digeneans follows Gibson et al. (2002), Jones et al. (2005) and Bray et al. (2008). The taxonomy of host follows Lavilla et al. (2010), Caramaschi (2006), Chaparro et al. (2007) and Zaher et al. (2009).

\section{SUBCLASS DIGENEA Carus, 1863}

Superfamily Diplostomoidea Poirier, 1886 Family Proterodiplostomidae Dubois, 1936

\section{Genus Heterodiplostomum Dubois, 1936}

Heterodiplostomum lanceolatum Dubois, 1936.

Host: South American water cobra, Hydrodynastes gigas (Duméril) (Serpentes, Dipsadidae).

Locality and date: El Colorado (26 $18^{\prime} \mathrm{S}, 5^{\circ} 22^{\prime} \mathrm{W}$ ), Department Pirané, Formosa Province, September 15, 2001.

Site of infection: large intestine.

Prevalence and intensity of infection: 1 of $1 ; 2$.

Material deposited: 2 specimens MLP 5504.

Comments: This species was found in Argentina parasitizing H. gigas from Corrientes Province; Bothrops alternatus Duméril, Bibron \& Duméril (Viperidae) from Santiago del Estero, Corrientes and Santa Fé Provinces; Helicops leopardinus (Schlegel) (Dipsadidae) from Chaco and Corrientes Provinces (Caubisens Poumarau 1968); and Helicops infrataeniatus Jan (Dipsadidae) from Buenos Aires (Lunaschi and Sutton 1985). This finding represents a new geographical record.

\section{SUPERFAMILY GORGODEROIDEA LoOSS, 1899.}

\section{Family Dicrocoeliidae Looss, 1899}

Genus Infidum Travassos, 1916

Infidum similis Travassos, 1916.

Host: Philodryas sp. (Serpentes, Dipsadidae).

Locality and date: La Marcela farm (26¹7'35" S, 5906'67" W), Department Pirané, Formosa Province; September 17, 2001.

Site of infection: gall bladder.

Prevalence and intensity of infection: 1 of $1 ; 2$.

Material deposited: 2 specimens MLP 5516.

Comments: This species was reported in Argentina by 
Caubisens Poumarau (1968) parasitizing the gall bladder of Philodryas olfersii Boulenger (Dipsadidae) from Padre Lozano, Salta Province. New geographical record.

\section{Family Gorgoderidae Looss, 1899}

\section{Genus Gorgoderina Looss, 1902}

Gorgoderina parvicava Travassos, 1922.

Host: creole frog, Leptodactylus latrans (Steffen) (Amphibia, Leptodactylidae).

Locality: Cuñá Pirú stream, Cainguás, Misiones Province (2705'14" S, 5457'11" W), July 23, 1998.

Site of infection: intestine.

Prevalence and intensity of infection: $10 \%$ (1 of 10); 1. Material deposited: 1 specimen MLP 5461.

Comments: Previous records of this species in Argentina include L. latrans from Buenos Aires Province (Suriano 1965; 1970). New geographical record.

\section{Family Mesocoeliidae Dollfus, 1929}

\section{Genus Mesocoelium Odhner, 1910}

Mesocoelium monas (Rudolphi, 1819) Freitas, 1958.

Hosts, localities and dates: rococo toad, Rhinella schneideri (Werner) (Amphibia, Bufonidae), Corrientes City (27²9' S, 58 49' W), March 19, 2002, and Sibynomorphus sp. (Serpentes, Dipsadidae), El Sombrerito stream, Corrientes Province (2738' S, 58 $44^{\prime}$ W), March 20, 2002.

Site of infection: intestine.

Prevalence and intensity of infection: R. schneideri $50 \%$ (1 of 2), 12; Sibynomorphus sp. 1 of 1, 13.

Material deposited: $R$. schneideri: 12 specimens MLP 5509; Sibynomorphus sp.: 13 specimens MLP 5512.

Comments: This species was reported in Argentina parasitizing the intestine of three species of snakes: Sibynomorphus ventrimaculatus (Boulenger) from Misiones and Chaco Provinces, Sibynomorphus turgidus (Cope) from Misiones and Entre Ríos Provinces, and Tomodon ocellatus Duméril, Bibron \& Duméril (Serpentes, Dipsadidae) from Buenos Aires Province (Caubisens Poumarau 1968). New host and new geographical record.

\section{SUPERFAMILY PARAMPHISTOMOIDEA Fischoeder, 1901}

\section{Family Diplodiscidae Cohn, 1904}

\section{Genus Catadiscus Cohn, 1904}

Catadiscus corderoi Mañé-Garzón, 1958

Host: creole frog, Leptodactylus latrans (Steffen) (Amphibia, Leptodactylidae).

Locality and date: Cuñá Pirú stream, Cainguás, Misiones Province (2705'14" S, 5457'11" W), July 23, 1998.

Site of infection: intestine.

Prevalence and intensity of infection: $10 \%$ (1 of 10); 6. Material deposited: 6 specimens MLP 5460.

Comments: At present, this species has only been reported parasitizing P. minutus as P. meridionalis Miranda-Ribeiro) (Amphibia, Pseudidae) from Uruguay (Mañé-Garzón 1958). New host and new geographical record.

Catadiscus dolichocotyle (Cohn, 1903) Cohn, 1904

Host: Philodryas sp. (Serpentes, Dipsadidae).

Locality and date: La Marcela farm (26¹7'35" S, 5906'67" W), Department Pirané, Formosa Province; September 17, 2001.

Site of infection: large intestine.

Prevalence and intensity of infection: 1 of $1 ; 4$.

Material deposited: 4 specimens MLP 5515.

Comments: At present, this species has been reported parasitizing Chironius fuscus (L.) (Serpentes, Colubridae) from Brazil and Liophis miliaris (L.) (Serpentes, Dipsadidae) from Uruguay (Travassos et al. 1969, Mañé-Garzón and Gortari 1965). This finding represents the first record of $C$. dolichocotyle in Argentina in a new host species.

Catadiscus uruguayensis Freitas \& Lent, 1939

Host: orange-legged monkey frog, Phyllomedusa azurea (Cope) (Amphibia, Hylidae).

Locality and date: Resistencia (27 $27^{\prime} 06^{\prime \prime}$ S, 58 59'10" W), Chaco Province; March 23, 1997.

Site of infection: stomach, large intestine.

Prevalence and mean intensity: $29 \%$ (5 of 17); 7.

Material deposited: 36 specimens MLP 3761B, 3761C, 3763 C, 3767C, 3769C, 3770C.

Comments: Previous records of this species in amphibians and reptiles of Argentina are restricted to the Province of Buenos Aires; as amphibian parasite, C. uruguayensis has been reported by Suriano (1970) in adults of $L$. latrans and by Ostrowski de Núñez (1979) in tadpoles of Hypsiboas pulchellus (Duméril \& Bibron) (as Hyla pulchela) (Amphibia, Hylidae) and adults of L. latrans and Pseudis minutus Günther (Amphibia, Pseudidae) [as Lysapsus mantidactylus (Cope)]. In reptiles, this digenean species has been reported by Lunaschi and Drago (2002) parasitizing Liophis poecilogyrus (Wied) (Dipsadidae). New host and new geographical record.

\section{Superfamily Plagiorchioidea Lühe, 1901}

Family Plagiorchiidae Lühe, 1901

\section{Genus Choledocystus Pereira \& Cuocolo, 1941}

Choledocystus elegans (Travassos, 1926) Ruiz 1949

Host: Creole frog, Leptodactylus latrans (Steffen) (Amphibia, Leptodactylidae).

Locality: Cuñá Pirú stream, Cainguás, Misiones Province (2705'14" S, 5457'11" W), July 23, 1998.

Site of infection: intestine, pancreas.

Prevalence and intensity of infection: $10 \%$ ( 1 of 10 ); 22

Material deposited: 22 specimens MLP 5459.

Comments: This species has been reported parasitizing L. latrans, Rhinella marina (L.) [as Bufo marinus (L.)] (Bufonidae) and Leptodactylus pentadactylus (Cope) (as L. pentadactylus labyrinthicus Spix) (Leptodactylidae) from Brazil (Ruiz 1949; Travassos et al. 1969; Noronha et 
al. 2009). This finding represents the first record of this species in Argentina.

\section{Genus Haplometroides Odhner, 1910}

\section{Haplometroides buccicola Odhner, 1911}

Host: coral snake, Micrurus corallinus (Merrem) (Serpentes, Elapidae).

Locality and date: Cuñá Pirú stream, Cainguás, Misiones Province (2705'14' S, 5457'11” W), March 15, 2000.

Site of infection: esophagus.

Prevalence and intensity of infection: 1 of 1 ; 1

Material deposited: 1 specimen MLP 5505.

Comments: Caubisens Poumarau (1968) reported this digenean species parasitizing the lung of the southern coral snake, Micrurus frontalis (Duméril, Bibron \& Duméril) (Elapidae) from Puerto Esperanza, Misiones, Argentina. New host and new geographical record.

\section{Genus Plagiorchis Lühe, 1899}

Plagiorchis luehei Travassos, 1927

Host: South American water cobra, Hydrodynastes gigas (Duméril) (Serpentes, Dipsadidae).

Locality and date: El Colorado (26 $18^{\prime} \mathrm{S}, 5^{\circ} 22^{\prime} \mathrm{W}$ ), Department Pirané, Formosa. Province, September 15, 2001.

Site of infection: mouth, esophagus.

Prevalence and intensity of infection: 1 of $1 ; 13$.

Material deposited: 13 specimens MLP 5501, MLP 5502. Comments: P. luehei (cited as Microderma luehei Travassos, 1927) was found in Argentina parasitizing H. gigas (as Cyclagras gigas Cope) from natural ecosystems from Corrientes and Chaco Provinces (Caubisens Poumarau 1968; Martínez et al. 1996). Later, it was reported in the same host from La Plata Zoological Garden, Buenos Aires Province (Lunaschi and Sutton 1985). New geographical record.

\section{Genus Travtrema Pereira, 1929}

Travtrema stenocotyle (Cohn, 1902)

Host: Philodryas sp. (Serpentes, Dipsadidae).

Locality and date: La Marcela farm $\left(26^{\circ} 17^{\prime} 35^{\prime \prime} \mathrm{S}\right.$, 5906'67" W), Department Pirané, Formosa Province; September 17, 2001.

Site of infection: esophagus, cloaca.

Prevalence and intensity of infection: 1 of $1 ; 12$.

Material deposited: 12 specimens MLP 5499, MLP 5500. Comments: Geographical distribution of this species in Argentine includes Buenos Aires, Corrientes, Chaco, Córdoba, Entre Ríos, La Rioja, Misiones, San Luis, Santa Fé, Santiago del Estero and Tucumán Provinces, parasitizing a large variety of dipsadid snakes: Clelia rustica (Cope), Liophis flavifrenatus (Cope), Liophis miliaris semiaureus (Cope), Liophis jaegeri (Günther), L. poecilogyrus, Philodryas patagoniensis (Girard), S. ventrimaculatus, Thamnodynastes pallidus L., Xenodon dorbignyi Duméril, Bibron \& Duméril, Xenodon merremi (Wagler), and viperid snakes, B. alternatus and Bothrops neuwedii diporus Cope (Lunaschi and Drago 2007). New geographical record.

\section{Family Telorchiidae Looss, 1899}

\section{Genus Telorchis Lühe, 1899}

Telorchis clava (Diesing, 1850)

Host: yellow anaconda, Eunectes notaeus Cope (Serpentes, Boidae).

Locality and date: La Marcela farm (26¹7'35" S, 5906'67" W), Department Pirané, Formosa Province; September 17, 2001.

Site of infection: small intestine.

Prevalence and intensity of infection: 1 of $1 ; 7$.

Material deposited: 7 specimens MLP 5511.

Comments: Previous records of T. clava in Argentinean reptiles include E. notaeus from Chaco (Caubisens Poumarau 1968), and to H.gigas from Corrientes (Martínez et al. 1996). New geographical record.

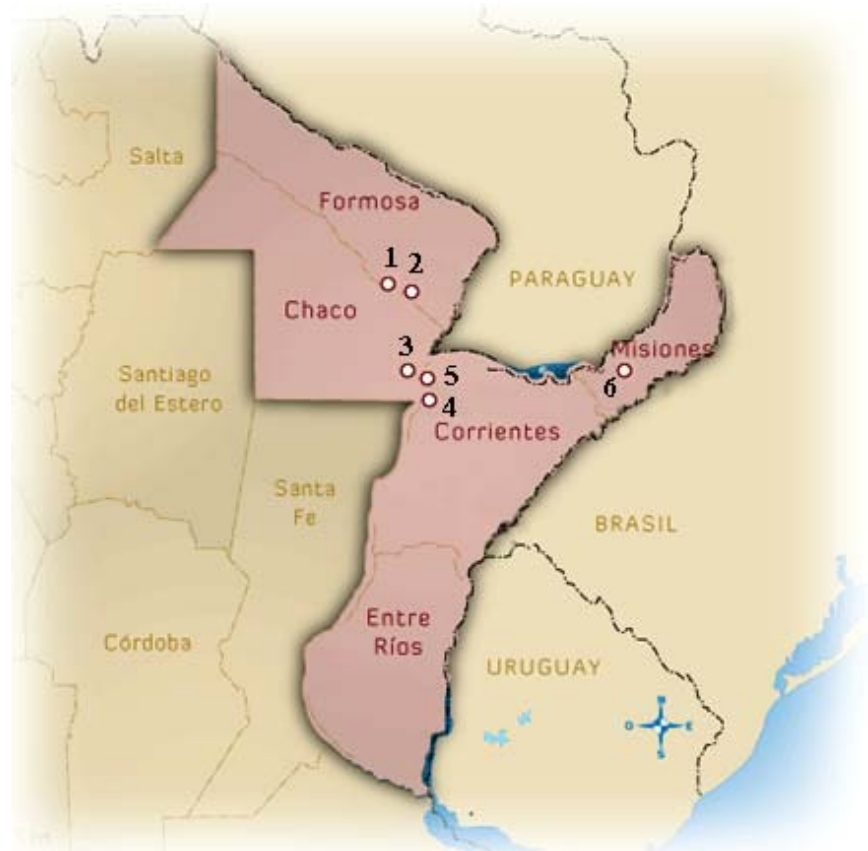

FIGURE 1. Map of northeastern Argentina showing the localities sampled: 1) El Colorado; 2) La Marcela farm; 3) Resistencia; 4) El Sombrerito stream; 5) Corrientes City; 6) Cuñá Pirú stream.

In this work, we extend the geographical distribution of 12 digenean species: C. corderoi, C. dolichocotyle, C. uruguayensis, Ch. elegans, G. parvicava, H. buccicola, $H$. lanceolatum, I. similis, M. monas, P. luehei, T. clava and T. stenocotyle. Three of them are reported for the first time in Argentina: C. dolichocotyle previously recorded only in Uruguay and Brazil, C. corderoi only reported in Uruguay, and Ch. elegans only registered in Brazil.

Three anuran species, $R$. schneideri, L. latrans and $P$. azurea are reported as new hosts of $M$. monas, $C$. corderoi and $C$. uruguayensis, respectively. Two ophidian species, $M$. corallinus and Philodryas sp. are presented as new hosts of $H$. buccicola and $C$. dolichocotyle, respectively.

Finally, two amphibian species ( $R$. schneideri and $P$. azurea), and one snake species (M. corallinus) are reported for the first time as digenean hosts in Argentina. These results highlight the need for further investigation and research on both groups of vertebrates. 
ACKNowledgments: This study was supported by grants from the Comisión de Investigaciones Científicas de la Provincia de Buenos Aires (CIC) (Res. № 578/08).The authors, Lía Lunaschi and Fabiana Drago are members of the Comisión de Investigaciones Científicas de la Provincia de Buenos Aires (CIC) and Universidad Nacional de La Plata (UNLP), respectively.

\section{LITERATURE Cited}

Bray R., D. Gibson and A. Jones. 2008. Keys to the Trematoda. Volume 3. London: CAB International. 824 p.

Caramaschi, U. 2006. Redefinição do grupo de Phyllomedusa hypochondrialis, com redescrição de P. megacephala (MirandaRibeiro, 1926), revalidação de P. azurea Cope, 1862 e descrição de uma nova espécie (Amphibia, Anura, Hylidae). Arquivos do Museu Nacional, Rio de Janeiro 64(2): 159-179.

Caubisens Poumarau, E.M. 1968. Trematodes de ofidios de la Argentina. Revista del Museo Argentino de Ciencias Naturales Bernardino Rivadavia, Parasitología 1(1): 1-129.

Chaparro, J.C., J.B. Pramuk and A.G. Gluesenkamp. 2007. A new species of arboreal Rhinella (Anura: Bufonidae) from cloud forest of Southeastern Peru. Herpetologica 63(2): 203-212.

Gibson, D., A. Jones and R. Bray. 2002. Keys to the Trematoda. Volume 1. London: CAB International. $521 \mathrm{p}$.

Jones, A, R. Bray and D. Gibson. 2005. Keys to the Trematoda. Volume 2. London: CAB International. $745 \mathrm{p}$.

Lavilla, E.O, J.A. Langone, U. Caramaschi, W. R. Heyer and R.O. De Sá. 2010 The identification of Rana ocellata Linnaeus, 1758. Nomenclatural impact on the species currently known as Leptodactylus ocellatus (Leptodactylidae) and Osteopilus brunneus (Gosse, 1851) (Hylidae). Zootaxa 2346: 1-16.

Lunaschi, L.I. and F. Drago. 2002. Primer registro de Catadiscus uruguayensis Freitas y Lent, 1939 (Digenea-Diplodiscidae) como parásito de reptiles. Neotropica 48: 65-67.

Lunaschi, L.I. and F. Drago. 2007. Checklist of digenean parasites of amphibians and reptiles from Argentina. Zootaxa 1476: 51-68.

Lunaschi, L.I. and C.A. Sutton. 1985. Trematodes de reptiles incorporados a la colección Helmintológica del Museo de La Plata. Neotropica 31(85): 69-81.
Mañé-Garzón, F. 1958. Un nouveau trematode des batraciens de l' Uruguay: Catadiscus corderoi n sp. Comunicaciones Zoológicas del Museo de Historia Natural de Montevideo 78(4): 1-5.

Mañe-Garzón, F. and A.M. Gortari. 1965. Sobre algunos trematodos de ofidios del Uruguay. Comunicaciones Zoológicas del Museo de Historia Natural de Montevideo 107(8): 1-21.

Martínez, F.A., J.C Troiano, J.L. Binda, D.E. Selles, D. Jara and N. Fescina 1996. Trematodes de algunos ofidios del norte argentino. Cuadernos de Herpetología 9(2): 85-94.

Noronha, D., M.R. Sá, M. Knoff, L.C. Muniz-Pereira and R.M. Pinto. 2009. Adolpho Lutz e a Coleção Helmintológica do Instituto Oswaldo Cruz, Rio de Janeiro. Rio de Janeiro: Museu Nacional. $154 \mathrm{p}$

Ostrowski de Núñez, M. 1979. Fauna de agua dulce de la Argentina. IX. Sobre representantes de la Familia Paramphistomatidae (Trematoda). Physis, Sección B 38(95): 55-62.

Ruiz, J.M. 1949. Considerações sôbre o gênero Choledocystus pereira \& Cuocolo, 1941(Trematoda, Plagiorchiidae). Revista Brasileira de Biologia 9(2): 167-174.

Suriano, D.M. 1965. Redescripción de Gorgoderina parvicava Travassos. Trematode de la vejiga urinaria de Leptodactylus ocellatus (L.) de la Rca. Argentina. Neotropica 11(34): 19-22.

Suriano, D.M. 1970. Estudio sobre la fauna parasitaria de Leptodactylus ocellatus (L.) (Anfibia-Leptodactylidae) de la República Argentina. Revista del Museo Argentino de Ciencias Naturales Bernardino Rivadavia, Zoología 10(15): 215-239.

Travassos, L., J.FT de Freitas and A. Kohn. 1969. Trematódeos do Brasil Memórias do Instituto Oswaldo Cruz 67: 1-866.

Zaher, H., F.G. Grazziotin, J.E. Cadle, R.W. Murphy, J.C. de Moura-Leite and S.L. Bonatto. 2009. Molecular phylogeny of advanced snakes (Serpentes, Caenophidia) with an emphasis on South American Xenodontines: a revised classification and descriptions of new taxa. Papéis Avulsos de Zoologia, São Paulo 49(11):115-153.

RECEIVED: May 2010

REVISED: June 2010

ACCEPTED: July 2010

Published Online: September 2010

EDITORIAL RESPONSIBILITY: Simone Chinicz Cohen 